\title{
Notes on Dicranella crispa and Schistidium confusum in Turkey
}

\author{
Ahmet UYGUR ${ }^{1 * i D}$, Tülay EZER ${ }^{2,3}$ iD, Seher KARAMAN ERKUL ${ }^{1}{ }^{\text {iD }}$, Mevlüt ALATAŞ ${ }^{4}$ iD \\ ${ }^{1}$ Aksaray University, Faculty of Science, Department of Biology, Aksaray, TURKEY \\ ${ }^{2}$ Niğde Ömer Halisdemir University, Faculty of Science, Department of Biology, Niğde, TURKEY \\ ${ }^{3}$ Niğde Ömer Halisdemir University, Faculty of Architecture, Department of Landscape Architecture, \\ Niğde, TURKEY \\ ${ }^{4}$ Munzur University, Vocational School of Tunceli, Department of Plant and Animal Production, Tunceli, \\ TURKEY
}

\begin{tabular}{lll}
\hline Received: 18.03.2020 & Revised: 09.04.2020 & Accepted: 13.04.2020
\end{tabular}

\begin{abstract}
In this study, both Dicranella crispa (Hedw.) Schimp (Dicranaceae) and Schistidium confusum H.H.Blom (Grimmiaceae) were recorded a second time from Mersin after Ardahan and Sakarya provinces and, also a first time from The Mediterranean region in Turkey. The specimens collected from the Taşeli Plateau. Description of the species is given along with their ecology and phytogeographical distribution.
\end{abstract}

Keywords: Bryophyte, Dicranella crispa, Schistidium confusum, Taşeli Plateau, Turkey.

\section{Türkiye'deki Dicranella crispa ve Schistidium confusum Üzerine Notlar}

\section{$\ddot{O ̈ z}$}

Dicranella crispa (Hedw.) Schimp (Dicranaceae) ve Schistidium confusum H.H.Blom (Grimmiaceae) bu çalışma ile Türkiye'de Ardahan ve Sakarya illerinden sonra ikinci kez Mersin'den ve ilk kez Akdeniz bölgesinden kaydedilmiştir. Örnekler Taşeli Platosu'ndan toplanmıştır. Türlerin tanımı ekolojileri ve fitocoğrafik dağılımları ile birlikte verilmiştir.

Anahtar kelimeler: Briyofit, Dicranella crispa, Schistidium confusum, Taşeli Platosu, Türkiye.

\footnotetext{
* Corresponding author: uygur3347@gmail.com

(C) 2020 All rights reserved / Tüm hakları saklıdır.

To cite this article: Uygur A. Ezer T. Karaman Erkul S. Alataş M. 2020. Notes on Dicranella crispa and Schistidium confusum in Turkey. Anatolian Bryology. 6:1, 64-69.

(c) (1) ) (9) This work is licensed under a Creative Commons Attribution-Non Commercial 4.0 International License.
} 


\section{Introduction}

The Taşeli Plateau, located between the provinces of Antalya-Karaman and Mersin, is a karst plateau with an area of 113460 ha located between the longitude of $32.73^{\circ} \mathrm{E}$ and the latitude of $36.38^{\circ}$ $\mathrm{N}$. The plateau is in Key Biodiversity Area (KBA) status due to its biodiversity (Eken et al., 2006).

The study area is located in the Mediterranean Phytogeographical Region, common vegetation of steppe exists at high altitude. Since the Taşeli Plateau is heavily covered with rocks, rock vegetation covers a large area. Moreover, the area also covered with Conifer forest in the southern and northern areas (Sümbül and Erik, 1988a, 1988b, 1990a, 1990b). According to the data of Anamur District Meteorology Station (URL-1), this locality has a rainy, warm Mediterranean climate (Akman, 2011). The mean annual temperature is $19.4^{\circ} \mathrm{C}$. The highest mean temperature is $33.0^{\circ} \mathrm{C}$ in August, and the lowest is $8.2^{\circ} \mathrm{C}$ in January. The mean annual precipitation of the region is $928.3 \mathrm{~mm}$. According to the data of Gülnar District Meteorology Station (URL-1), this locality has also rainy, warm Mediterranean climate (Akman, 2011). The mean annual temperature is $13.4^{\circ} \mathrm{C}$. The highest mean temperature is $30.2^{\circ} \mathrm{C}$ in August, and the lowest is $0.4^{\circ} \mathrm{C}$ in January. The mean annual precipitation of the region is $762.8 \mathrm{~mm}$.

The genus Dicranella (Dicranaceae) represented with 7 taxa and the genus Schistidium (Grimmiaceae) represented with 22 taxa in Turkey (Karakaş and Ezer, 2016; Erdağ and Kürschner, 2017; Batan et al., 2018; Uyar et al., 2018). Dicranella crispa and Schistidium confusum are reported second time from Turkey, former taxon first time reported Ardahan and later taxon first time reported Sakarya province where are located from Euro-Siberian Phytogeographical Region with this study. Moreover, these species are recorded the first time from the Mediterranean Region (Figure 1,2).

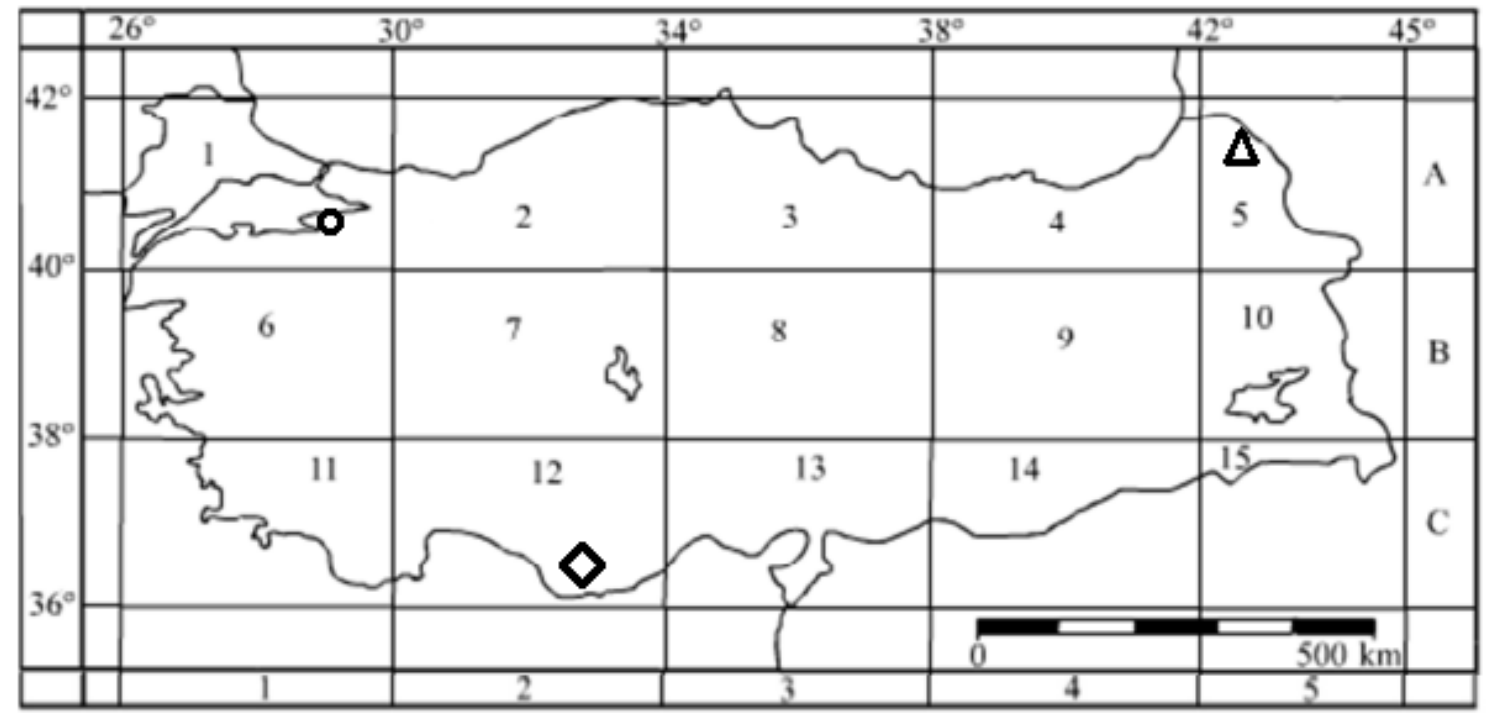

Figure 1. D. crispa and S. confusum distribution in Turkey (Henderson, 1965). $\Delta$ Dicranella crispa, O Schistidium confusum, $\diamond$ Location of the research area 


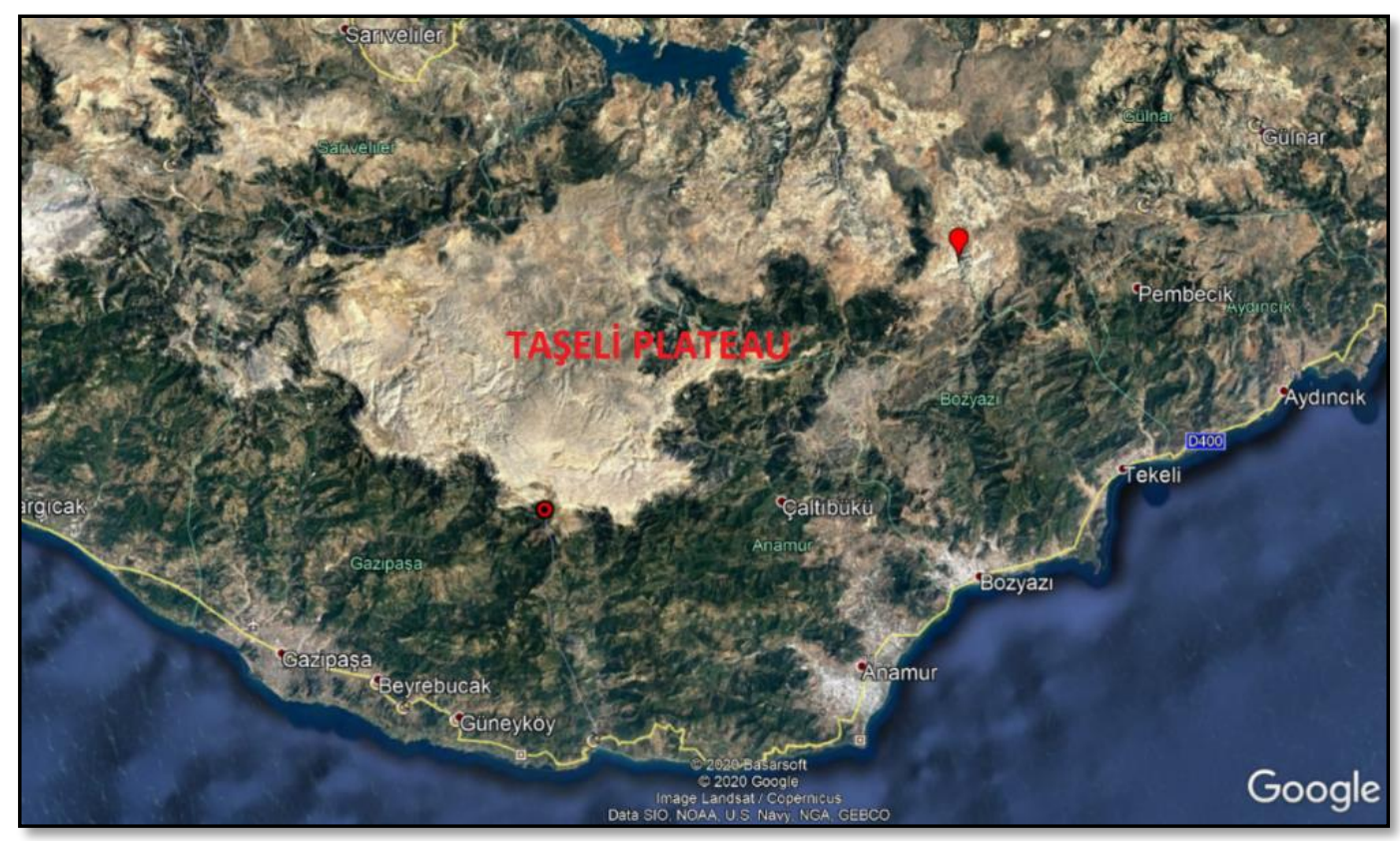

Figure 2. D. crispa and S. confusum location in Taşeli Plateau (changed from Google Earth)

2. Dicranella crispa

\section{Materials and Methods}

Dicranella and Schistidium specimens were collected during the bryological investigations in Taşeli Plateau. The collected specimens were prepared according to standard herbarium techniques and identified using various flora and revisional studies; Nyholm, 1986, 1998; Blom, 1996; Noguchi and Iwatsuki, 1987; Smith, 2004; Frey et al., 2006. Voucher specimens were stored in standard bryophyte envelope in Herbarium of Scientific and Technological Application and Research Center, Aksaray University (AKSU).

\section{Results and Discussion}

Dicranella crispa (Hedw.) Schimp.

Specimen examined: Turkey, Mersin province, Bozyazı district, Dereköy village, Dereköy freshwater trout facility surroundings $\left(36^{\circ} 20^{\prime}\right.$ 23.9388" N-33 4'31.8504" E), on rock, $1100 \mathrm{~m}$, 22.08.2019, A. UYGUR 1496.

Taxa belong to $D$. crispa are diagnosed with lightly crisped leaves when dry, squarrose leaves when moist, plane leaf margin at base, denticulate leaf margin towards the apex. The plant is 5-10 $\mathrm{mm}$ long and seen green tufts. Leaves are 2-4 mm long and reflexed backward. Basal leaf cell is linear to rectangular (Fig. 3). Mid-leaf cell is narrower, linear, 4-6 $\mu \mathrm{m}$ wide. Sporophytes were not seen in our population. D. crispa is similar to
D. gravilleana (Brid.) Schimp. but it is differentiated upper rectangular narrow leaf cell (rectangular cell) and rhizoidal gemmae is absent (has reddish brown rhizoidal gemmae) (Ireland, 1982; Nyholm, 1986; Smith, 2004; Frey et al., 2006).

D. crispa is circumpolar, acidophytic, mesophytic, sciophytic specimen. Its habitat is open on bare clayey, loamy, sandy and gravelly banks and alluvial sands, by streams, river and roadsides, on ditches, in sands or clay pits (Dierßen, 2001; Smith, 2004). Dereköy village has a freshwater spring. Specimens were collected on a rock from under poplar tree around freshwater spring.

D. crispa which is including in the IUCN Red List of Threatened Species in the LC category in Europe (Cogoni et al. 2019) spreads in Europe (including Svalbard in the north, Italy, Denmark, Finland, Norway, Faeroe Islands, Sweden, France, Great Britain, Ireland, Austria, Czech Republic, Germany, Netherlands, Poland, Slovakia, Switzerland, Hungary, Romania, Slovenia, Iceland), Siberia, N. Asia, N. America, Greenland and China (Nyholm, 1986; Noguchi and Iwatsuki, 1987; Smith, 2004; Frey et al., 2006; Ros et al., 2013; Hodgetts, 2015; Gulnigar et al., 2018). 


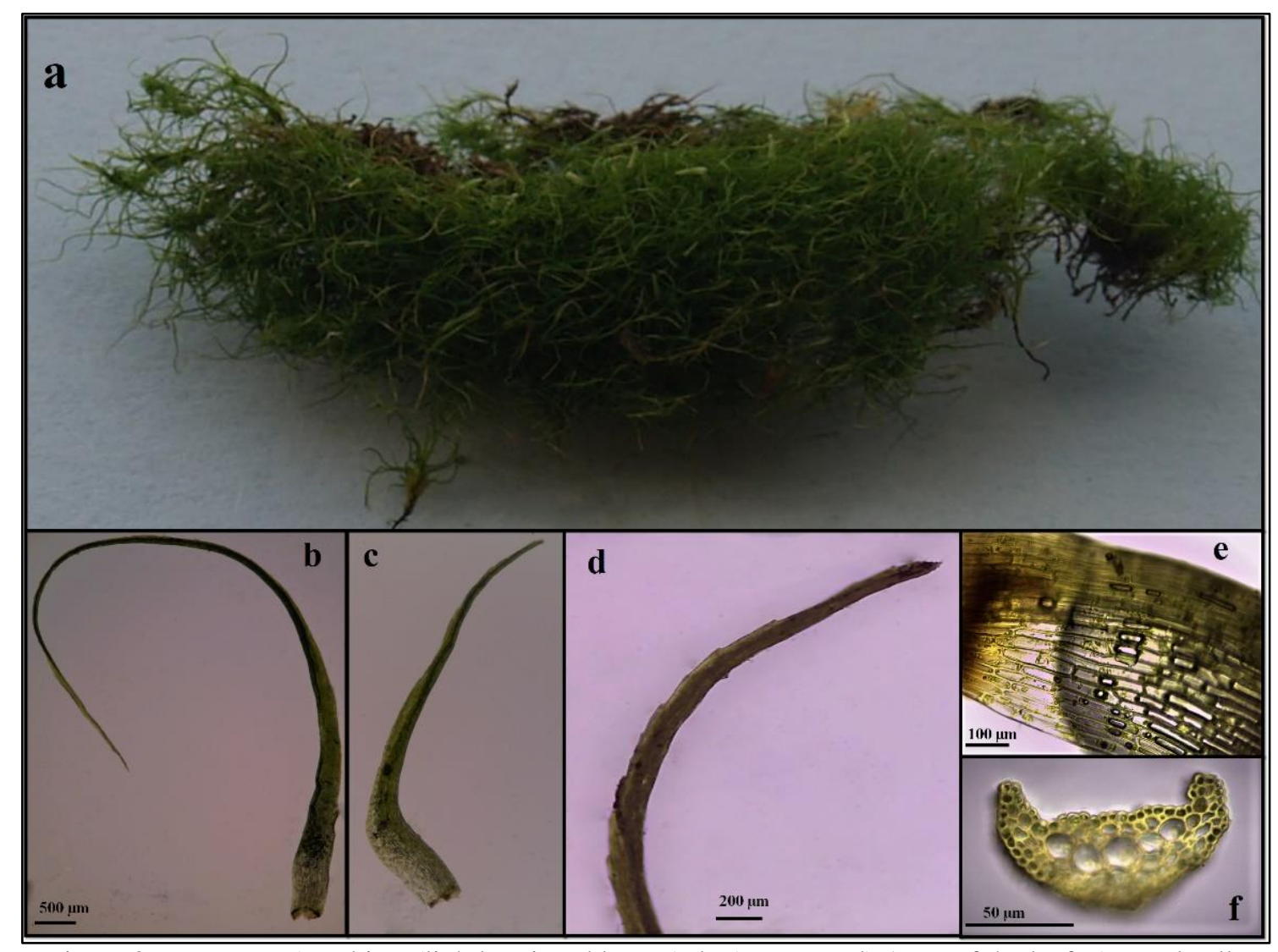

Figure 3. D. crispa. a) Habitus (lightly crisped leaves), b-c) Leaves, d) Apex of the leaf, e) Basal cell,

f) Cross-section of leaf

\section{Schistidium confusum H.H.Blom}

Specimen examined: Turkey, Mersin province, Anamur district, Kaş plateau $\left(36^{\circ} 17^{\prime} 28.6584^{\prime \prime N}\right.$ $32^{\circ} 36^{\prime} 47.7864^{\prime \prime E}$ ), on rock, alt.1950 m, 28.06.2019, A. UYGUR 1011.

S. confusum has recurved leaf margins, narrow and rigid hair points, strongly sinuose leaf cells. Upper leaf lamina bistratose, costa strong, peristome teeth squarrose and capsule oblong. Perichaetial leaves are longer than capsule (Nyholm, 1998; Blom, 1996, Uyar et all., 2018, Fig. 4).

S. confusum is basiphytic, xerophytic, thermophytic plant. They grow on calcareous rocks, seashore cliffs and rood cutting. Their habitat is under deciduous forest or sun-exposed areas (Dierßen, 2001; Hallingback et al., 2006). In the first locality of $S$. confusum in Turkey, the species was collected under Quercus forest at deciduous forest edge, on calcareous rock at 150 m (Uyar et al., 2018); the second locality of $S$. confusum in the present study was collected from calcareous rock in the sun-exposed area at $1950 \mathrm{~m}$ and together with Grimmia pulvinata (Hedw.) Sm. The presence of $S$. confusum which has xerophytic character at the high altitude of the study area may be due to the climate characteristics of the study area and presence of arid rocky habitats in the study area. Also, $S$. confusum is included in the IUCN Red List of Threatened Species in the LC category in Europe (Schröck, 2019).

S. confusum is known from Turkey, Austria, Czech Republic, Estonia, Finland, Hungary, Latvia, Norway, North-Western European Russia, and Sweden (Nyholm, 1998; Ignatov et al., 2006, Ros et al., 2013, Uyar et al., 2018). 


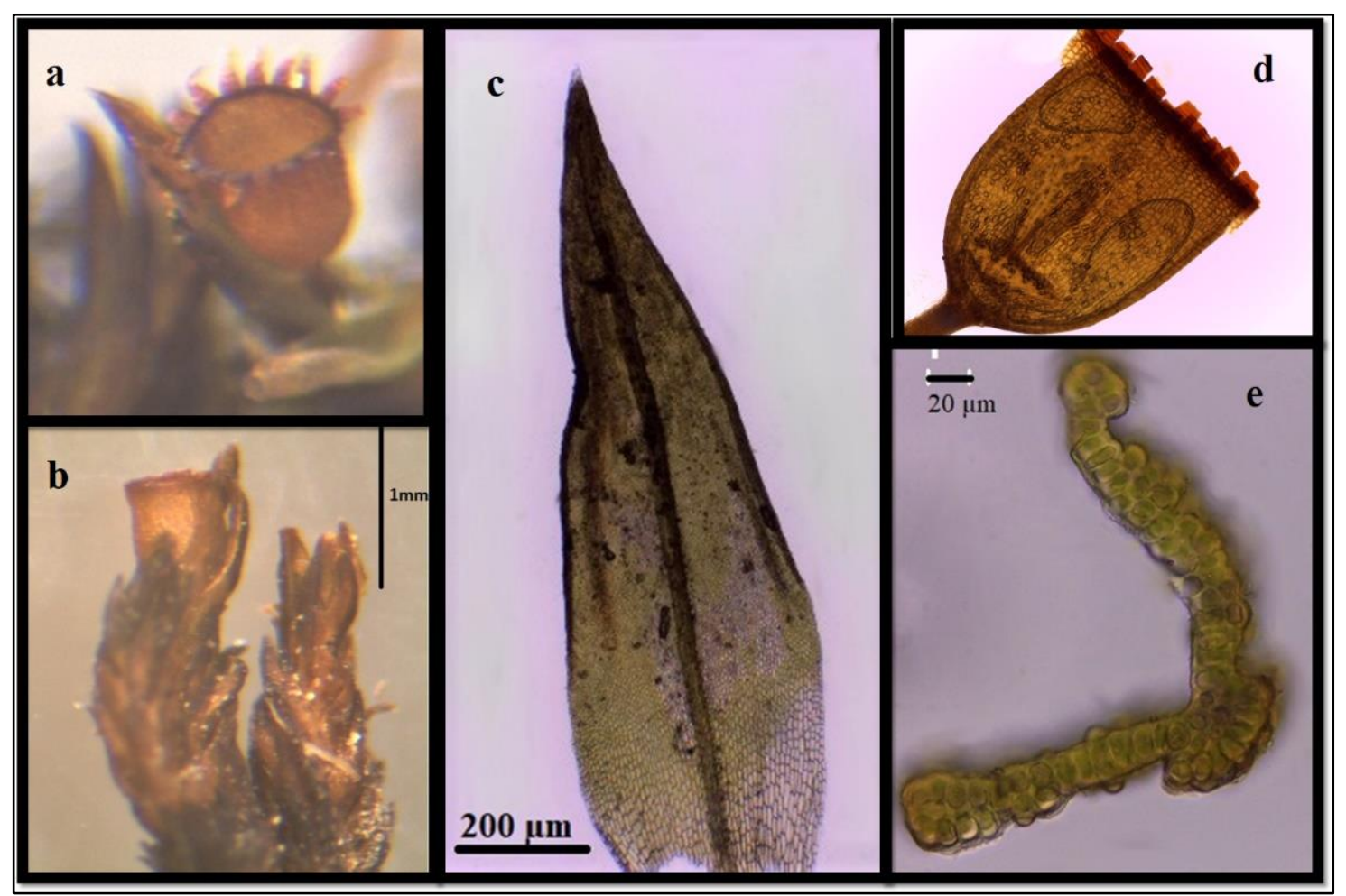

Figure 4. S. confusum. a) Capsule b) Habit c) Leaf d) Capsule (10x) e) Cross-section of leaf

\section{Acknowledgements}

This study was financially supported by the Scientific and Technological Research Council of Turkey (TÜBITAK) (Project No: 120Z046). We would like to thank for its financial support.

\section{References}

Akman Y. 2011. İklim ve Biyoiklim (Biyoiklim metodları ve Türkiye İklimleri). Palme Yayıncilık. Ankara.

Batan N. Alataş M. Erata H. Özdemir T. 2019. Two remarkable moss species new to Turkey and South-west Asia. Plant Biosystems. 153:2,195-198.

Blom H.H. 1996. A Revision of the Schistidium apocarpum complex in Norway and Sweden. Bryophytorum Bibliotheca. 49, 1334.

Cogoni A. Campisi P. Garcia C. Hallingbäck T. Hodgetts N. Kucera J. Lara F. Lüth M. 2019. Dicranella crispa. The IUCN Red List of Threatened Species 2019: e. T84720560A87768738. [Accessed: 29 February 2020].

Cortini Pedrotti C. 2001. Flora dei muschi d'Italia, Sphagnopsida, Andreaopsida, Bryopsida (I parte). Medicina-Scienze. Roma.

Dierßen K. 2001. Distribution, ecological amplitude and phytosociological characterization of European bryophytes. Bryophytorum Bibliotheca. 56, 1-289.
Eken G. Bozdoğan M. İsfendiyaroğlu S. Kılıç D.T. Lise Y. 2006. Key Biodiversity Areas of Turkey. Nature Conservation Association. Ankara.

Erdağ A. Kürschner H. 2017. The list of Turkey plants (mosses). Ali Nihat Gökyiğit Foundation Press. İstanbul.

Frey W. Frahm J.P. Fischer E. Lobin W. 2006. The liverworts, mosses and ferns of Europe. Gustav Fischer Verlag. Heidelberg.

Gulnigar A. Molla A. Sulayman M. Wu P. 2018. Introduction of the newly recorded bryophytes to China, from the investigation of Xinjiang in the last decade. Chenia, Contributions to Cryptogamic Biology. 13, 39-61.

Hallingback T. Lönnell N. Weibull H. Hedenas L. 2006. Nationalnyckeln Till Sveriges Flora och Fauna, Bladmossor: Sköldmossor Blamossor, Bryophyta: Buxbaumia Leucobryum. Upsala, ArtDatabanken, 416 $\mathrm{p}$.

Hodgetts N.G. 2015. Checklist and country status of European bryophytes - towards a new red list for Europe. Ireland: National Parks and Wildlife Service.

Ireland R. 1982. Moss flora of maritime provinces, Ottova: National Museum of Natural Sciences, Publication in Botany No: 13. 
Karakaş M. Ezer T. 2016. Two new moss records in the family Grimmiaceae from Turkey. Telopea. 19, 65-72.

Noguchi A. Iwatsuki Z. 1987. Illustrated moss flora of Japan (Part 1). The Hattori Botanical Laboratory. Miyazaki.

Nyholm E. 1986. Illustrated flora of Nordic mosses (Fasc. 1) Fissidentaceae Seligeriaceae, The Nordic Bryological Society. Lund.

Nyholm E. 1998. Illustrated flora of Nordic mosses, Fasc. 4. Aulacomniaceae Meesiaceae -Catoscopiaceae Bartramiaceae - Timmiaceae Encalyptaceae - Grimmiaceae Ptychomitraceae - Hedwigiaceae Orthotrichaceae. Copenhagen, Nordic Bryological Society.

Ros R.M. Mazimpaka V. Abou-Salama U. Aleffi M. Blockeel T.L. Brugués M. Cros R.M. Dia M.G. Dirkse G.M. Draper I. et al. 2013. Mosses of the Mediterranean, an annotated checklist. Cryptogamie Bryologie. 34, 99-283.

Schröck C. 2019. Schistidium confusum. The IUCN Red List of Threatened Species 2019: e. T85845832A87736065. [Accessed: 29 February 2020].

Smith A.J.E. 2004. The moss flora of Britain and Ireland, Cambridge (GB): Cambridge University Press.

Sümbül H. Erik S. 1988a. Flora of Taseli Platosu I, Doğa Türk Bot. Derg. 12:2, 175-205.

Sümbül H. Erik, S. 1988b. Flora of Taseli Platosu II, Doğa Türk Bot. Derg. 12:3, 254-322.

Sümbül H. Erik, S. 1990a. Flora of Taseli Platosu III, Hacettepe Fen ve Müh. Bil. Derg. 2, 138.

Sümbül H. Erik S. 1990b. Flora of Taseli Platosu IV, Hacettepe Fen ve Müh. Bil. Derg. 2, 61-120.

Uyar G. Ören M. Ezer T. Gözcü M.C. 2018. The genus Pseudephemerum and Schistidium confusum newly reported from Turkey and Southwestern Asia. Cryptogamie, Bryologie. 39:1, 55-60.

URL-1. Meteorological Data Information Sales and Presentation System. Website: https://mevbis.mgm.gov.tr/mevbis/ui/inde x.html\#/Workspace. [Accessed: 21 June 2019]. 